\title{
Pengaruh Brand Experience Dan Keterlibatan Merek Terhadap Loyalitas Merek Melalui Kepercayaan Dan Komitmen Merek Pada E-Commerce Sociolla
}

\author{
Antonia Dewanti Adiningtyas Pramushinta ${ }^{1}$, dan Sheellyana Junaedi ${ }^{2}$ \\ Fakultas Bisnis dan Ekonomika, Universitas Atma Jaya Yogyakarta ${ }^{1,2}$ \\ \{antoniadewanti.ap@gmail.com ${ }^{1}$, sheellyana.junaedi@uaiy.ac.id $\left.{ }^{2}\right\}$
}

\begin{abstract}
Abstrak: Penelitian ini memiliki tujuan untuk menganalisis pengaruh Brand Experience dan Keterlibatan Merek terhadap Loyalitas Merek dengan Kepercayaan Merek dan Komitmen Merek sebagai variabel pemediasi pada objek beauty e-commerce Sociolla. Pada penelitian ini disebarkan kuesioner secara online untuk jumlah sampel 331 responden dengan kriteria wanita yang pernah melakukan pembelian melalui aplikasi beauty e-commerce SOCO by Sociolla minimal 2 kali dalam 1 tahun terakhir. Penelitian ini bersifat tidak acak yaitu purposive sampling. Pembagian kuesioner dilakukan dengan menggunakan aplikasi Google Forms. Lalu, link kuesioner disebarkan secara online melalui berbagai media sosial seperti Whatsapp, Line, Instagram, Linkedln dan Twitter. Analisis data dilakukan menggunakan Structural Equation Modeling (SEM), dengan bantuan software Partial Least Square (PLS). Pada hasil pertama penelitian ini diketahui bahwa Brand Experience dan Keterlibatan Merek berpengaruh secara langsung dan signifikan terhadap Kepercayaan Merek. Hasil kedua penelitian ini diketahui bahwa Kepercayaan Merek berpengaruh secara langsung dan signifikan terhadap Komitmen Merek. Hasil ketiga penelitian ini diketahui bahwa Komitmen Merek berpengaruh secara langsung dan signifikan terhadap Loyalitas Merek. Hasil keempat penelitian ini diketahui bahwa Kepercayaan Merek memediasi pengaruh Brand Experience dan Keterlibatan Merek terhadap Komitmen Merek menunjukkan pengaruh yang signifikan. Hasil kelima penelitian ini diketahui bahwa Komitmen Merek memediasi pengaruh Keterlibatan Merek dan Kepercayaan Merek terhadap Loyalitas Merek menunjukkan pengaruh yang signifikan, namun Komitmen Merek tidak memediasi pengaruh Brand Experience terhadap Loyalitas Merek yang menunjukkan tidak adanya pengaruh yang signifikan.
\end{abstract}

Kata kunci: Brand Experience, Keterlibatan Merek, Loyalitas Merek, Kepercayaan Merek, dan Komitmen Merek

Perkembangan e-commerce di Indonesia semakin meningkat dari tahun ke tahun. Salah satunya karena jumlah peningkatan pengguna internet di Indonesia. Berdasarkan data dari Global Web Index, pada tahun 2019 negara Indonesia menjadi negara dengan tingkat adopsi e-commerce tertinggi di dunia. Pembelian secara online sebesar $90 \%$ berasal dari pengguna internet dari usia 16 hingga 64 tahun yang melakukan pembelian online barang dan jasa (https://www.cnnindonesia.com). Data yang dirilis dalam website ekonomi bisnis menunjukkan produk kecantikan mengalami peningkatan penjualan di setiap tahun yang ditunjukkan dengan pendapatan pasar dari penjualan produk kecantikan dan perawatan tubuh di Indonesia hampir menyentuh angka US\$6,9 miliar tahun 2019 yang menunjukkan jika minat masyarakat yang besar terhadap suatu produk (https://ekonomi.bisnis.com). Beauty e-commerce Sociolla saat ini menjadi situs kosmetik nomor satu di Indonesia. Melalui 
situs website dan aplikasi SOCO by Sociolla mampu menghadirkan produk kecantikan dari berbagi merek dan produk yang ditawarkan merupakan produk kecantikan dengan kualitas premium. SOCO by Sociolla adalah aplikasi yang dapat diunduh melalui smartphone atau platform komunitas yang melengkapi Sociolla sehingga pengguna dapat berbelanja produk kosmetik, mendapatkan rekomendasi kecantikan yang dipersonalisasi, konten kecantikan yang relevan, berbagi ulasan, dan terhubung dengan penggemar kecantikan lainnya (https://dailysocial.id/). Loyalitas merek dipengaruhi oleh kredibilitas dan niat konsumen untuk membeli atau melakukan pembelian ulang secara terus menerus dan melakukan proses dengan cara merekomendasikan merek tersebut kepada orang lain, kesediaan untuk membayar lebih dan tidak adanya keluhan terhadap penggunaan produk atau jasa (Frimpong et al., 2019). Konsumen pada umumnya memiliki keinginan dalam niat melakukan pembelian yang lebih tinggi dengan merek yang dikenali dengan mudah. Komitmen merek terdiri dari dua dimensi yaitu kesinambungan dan komitmen afektif (Khan et al., 2019). Brand experience didefinisikan sebagai tanggapan dari konsumen yang dapat ditemukan melalui sensasi, perasaan, kognitif, dan respon perilaku yang ditimbulkan oleh rangsangan yang berkaitan dengan merek dari sisi desain dan identitas, komunikasi, pengemasan, dan lingkungan (Khan et al., 2019). Dalam layanan online seperti adanya e-commerce, kepercayaan yang telah tercapai diidentifikasi sebagai faktor keberhasilan utama mengingat tidak adanya interaksi secara fisik dan fisik pembeli/jarak layanan (Bilgihan, 2016). Keterlibatan merek (brand engagement) didefinisikan sebagai keadaan psikologis yang terjadi berdasarkan pelanggan yang interaktif pada pengalaman dengan agen/objek fokus dalam layanan hubungan suatu merek (Khan et al., 2019). Penelitian ini bertujuan untuk melakukan pengujian pada pengaruh Brand Experience dan Keterlibatan Merek terhadap Loyalitas Merek pada situs Beauty e-commerce Sociolla serta menguji Kepercayaan Merek dan Komitmen Merek yang berperan sebagai variabel mediasi (mediating variable). Berdasarkan pembahasan perumusan masalah sebelumnya, maka tujuan penelitian yang ingin dicapai adalah untuk menganalisis pengaruh brand experience dan keterlibatan merek terhadap loyalitas merek melalui kepercayaan dan komitmen merek sebagai mediasi pada e-commerce Sociolla. Hipotesis sebagai berikut:

H1 dan H2: Brand Experience dan Keterlibatan Merek berpengaruh terhadap Kepercayaan Merek

H3: Kepercayaan Merek berpengaruh terhadap Komitmen Merek

H4: Komitmen Merek berpengaruh terhadap Loyalitas Merek

H5 dan H6: Kepercayaan Merek memediasi pengaruh antara Brand Experience dan Keterlibatan Merek terhadap Komitmen Merek

H7, H8, dan H9: Komitmen merek memediasi pengaruh antara Brand Experience, Keterlibatan Merek, dan Kepercayaan Merek terhadap Loyalitas Merek 
H9

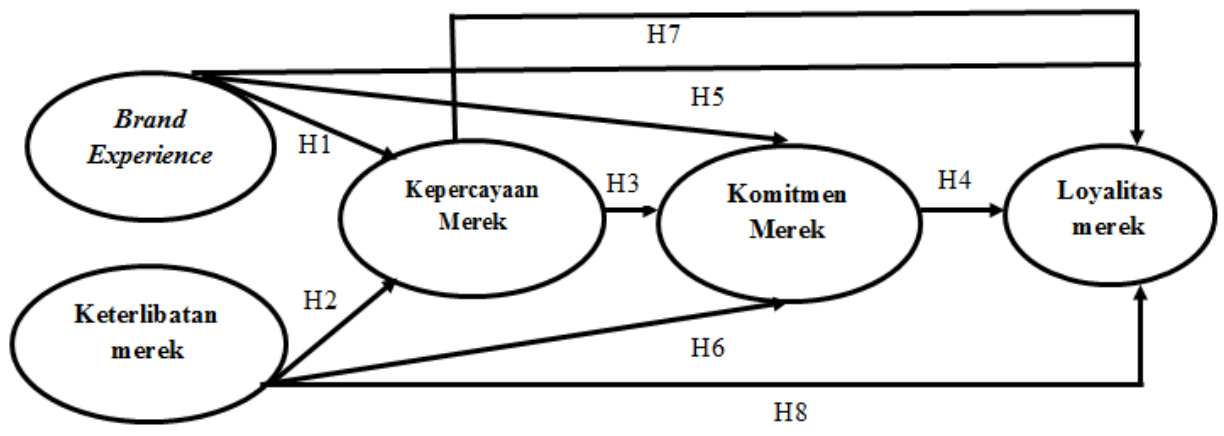

Gambar 1. Model Penelitian

Sumber: Khan, et al. (2019: 164)

\section{METODE}

Penelitian ini dilakukan menggunakan metode kuantitatif dengan mengumpulkan data primer melalui proses menyebarkan kuesioner secara online melalui link kuesioner dengan menggunakan aplikasi Google Forms kepada para responden sesuai dengan penelitian sebelumnya (Khan, et al., 2019). Populasi dari penelitian ini adalah wanita yang pernah membeli produk melalui aplikasi beauty e-commerce SOCO by Sociolla. Pada penelitian ini peneliti menentukan sampel (Purposive Sampling) yaitu pada wanita yang pernah membeli produk di aplikasi beauty e-commerce SOCO by Sociolla minimal 2 kali dalam 1 tahun terakhir. Ukuran sampel minimum yang digunakan dalam penelitian ini menggunakan sample size untuk SEM. Model persamaan SEM adalah teknik analisis yang dilakukan secara multivariate generasi kedua (Second Generation) dengan cara menggabungkan analisis faktor (Factor Analysis) dengan analisis jalur (Path Analysis) melalui variabel laten (Ghozali \& Latan, 2015). Untuk melakukan pengujian seluruh hipotesis dalam penelitian ini menggunakan metode SEM-PLS.

Tabel 1. Demografi Responden ( $n=331$ responden)

\begin{tabular}{|c|c|c|c|c|}
\hline No & Demografi & Karakteristik & Jumlah & Persentase \\
\hline \multirow{2}{*}{1} & \multirow{2}{*}{ Jenis Kelamin } & Wanita & 331 & $100 \%$ \\
\hline & & Pria & - & - \\
\hline \multirow{2}{*}{2} & \multirow{2}{*}{$\begin{array}{c}\text { Pernah melakukan } \\
\text { pembelian melalui beauty } \\
\text { e-commerce Sociolla }\end{array}$} & Ya Pernah & 331 & $100 \%$ \\
\hline & & Tidak Pernah & - & - \\
\hline \multirow{2}{*}{3} & \multirow{2}{*}{$\begin{array}{l}\text { Memiliki aplikasi SOCO by } \\
\text { Sociolla di smartphone }\end{array}$} & Ya Memiliki & 331 & $100 \%$ \\
\hline & & Tidak Memiliki & - & - \\
\hline \multirow{5}{*}{4} & \multirow{5}{*}{$\begin{array}{l}\text { Intensitas berbelanja di } \\
\text { beauty } \\
\text { commerce Sociolla dalam } \\
\text { satu tahun terakhir }\end{array}$} & 1 kali & - & - \\
\hline & & 2 kali & 86 & $25,98 \%$ \\
\hline & & 3 kali & 67 & $20,24 \%$ \\
\hline & & 4 kali & 37 & $11,18 \%$ \\
\hline & & $\geq 5$ kali & 141 & $42,60 \%$ \\
\hline 5 & Usia (Tahun) & $16-20$ & 103 & $31,12 \%$ \\
\hline
\end{tabular}




\begin{tabular}{|c|c|c|c|c|}
\hline & & $21-25$ & 167 & $50,45 \%$ \\
\hline & & $26-30$ & 47 & $14,20 \%$ \\
\hline & & $\geq 31$ & 14 & $4,23 \%$ \\
\hline \multirow{5}{*}{6} & \multirow{5}{*}{ Pekerjaan } & Mahasiswi & 179 & $54,08 \%$ \\
\hline & & Karyawati & 85 & $25,68 \%$ \\
\hline & & Wiraswasta & 21 & $6,34 \%$ \\
\hline & & Ibu Rumah Tangga & 19 & $5,74 \%$ \\
\hline & & Lainnya & 27 & $8,16 \%$ \\
\hline \multirow{4}{*}{7} & \multirow{4}{*}{$\begin{array}{l}\text { Rata-rata biaya yang } \\
\text { dikeluarkan dalam setiap } \\
\text { pembelanjaan di Sociolla }\end{array}$} & $\leq \operatorname{Rp} 100.000$ & 73 & $22,05 \%$ \\
\hline & & $\operatorname{Rp} 100.001-\operatorname{Rp} 200.000$ & 144 & $43,50 \%$ \\
\hline & & Rp $200.001-R p 300.000$ & 64 & $19,34 \%$ \\
\hline & & $\geq \operatorname{Rp} 300.001$ & 50 & $15,11 \%$ \\
\hline \multirow{4}{*}{8} & \multirow{4}{*}{$\begin{array}{l}\text { Pendapatan/uang saku } \\
\text { perbulan }\end{array}$} & $\leq \operatorname{Rp} 2000.000$ & 146 & $44,11 \%$ \\
\hline & & Rp $2000.001-R p 4000.000$ & 76 & $22,96 \%$ \\
\hline & & Rp $4000.001-\operatorname{Rp} 6000.000$ & 41 & $12,39 \%$ \\
\hline & & $\geq \operatorname{Rp} 6000.001$ & 68 & $20,54 \%$ \\
\hline \multirow{6}{*}{9} & \multirow{6}{*}{$\begin{array}{l}\text { Produk yang pernah dibeli } \\
\text { melalui beauty e-commerce } \\
\text { Sociolla }\end{array}$} & Makeup & 255 & $77,04 \%$ \\
\hline & & Skincare & 314 & $94,86 \%$ \\
\hline & & Hair Care & 56 & $16,92 \%$ \\
\hline & & Bath \& Body & 87 & $26,28 \%$ \\
\hline & & Accessories Tools Make-up & 68 & $20,54 \%$ \\
\hline & & Lainnya: Gift Card & 1 & $0,30 \%$ \\
\hline \multirow{7}{*}{10} & \multirow{7}{*}{$\begin{array}{c}\text { Fitur pembayaran yang } \\
\text { digunakan dalam } \\
\text { pembelian produk di beauty } \\
\text { e-commerce Sociolla }\end{array}$} & Virtual Account Bank & 191 & $57,70 \%$ \\
\hline & & ShopeePay & 135 & $40.79 \%$ \\
\hline & & OVO Payment & 126 & $38,07 \%$ \\
\hline & & Gopay & 103 & $31,12 \%$ \\
\hline & & Credit Card & 26 & $7,85 \%$ \\
\hline & & Transfer Bank & 96 & $29,00 \%$ \\
\hline & & Minimarket (Indomaret) & 36 & $10,88 \%$ \\
\hline \multirow{5}{*}{11} & \multirow{5}{*}{$\begin{array}{l}\text { Sumber mengetahui } \\
\text { tentang beauty e- } \\
\text { commerce Sociolla }\end{array}$} & Teman atau saudara & 94 & $28,40 \%$ \\
\hline & & Website & 99 & $29,91 \%$ \\
\hline & & Media sosial & 284 & $85,80 \%$ \\
\hline & & Iklan & 70 & $21,15 \%$ \\
\hline & & Lainnya & 2 & $0,60 \%$ \\
\hline
\end{tabular}

Sumber: Data yang diolah (2020)

Tabel 2. Hasil Validitas Konvergen dan Reliabilitas

\begin{tabular}{|c|c|c|c|c|c|c|}
\hline No. & Konstruk & Indikator & Outer Loading & AVE & Cronbach's Alpha & CR \\
\hline \multirow{4}{*}{1} & \multirow{3}{*}{$\begin{array}{c}\text { Brand } \\
\text { Experience }\end{array}$} & BE1 & 0.716 & & & \\
\cline { 3 - 4 } & & BE2 & 0.775 & & \\
\cline { 3 - 4 } & & BE3 & 0.7852 & 0.821 & 0.874 \\
\cline { 3 - 4 } & & BE4 & 0.755 & & & \\
\hline
\end{tabular}




\section{PROSIDING SEMINAR NASIONAL EKONOMI DAN BISNIS 2021}

\section{UNIVERSITAS MUHAMMADIYAH JEMBER}

\begin{tabular}{|c|c|c|c|c|c|c|}
\hline \multirow{11}{*}{2} & & BE5 & 0.781 & & & \\
\hline & \multirow{10}{*}{$\begin{array}{l}\text { Keterlibatan } \\
\text { Merek }\end{array}$} & KTM1 & 0.619 & \multirow{10}{*}{0.758} & \multirow{10}{*}{0.894} & \multirow{10}{*}{0.913} \\
\hline & & KTM2 & 0.753 & & & \\
\hline & & KTM3 & 0.680 & & & \\
\hline & & KTM4 & 0.748 & & & \\
\hline & & KTM5 & 0.800 & & & \\
\hline & & KTM6 & 0.696 & & & \\
\hline & & KTM7 & 0.722 & & & \\
\hline & & KTM8 & 0.630 & & & \\
\hline & & KTM9 & 0.735 & & & \\
\hline & & KTM10 & 0.761 & & & \\
\hline \multirow{3}{*}{3} & \multirow{3}{*}{$\begin{array}{c}\text { Kepercayaan } \\
\text { Merek }\end{array}$} & KPM1 & 0.862 & \multirow{3}{*}{0.513} & \multirow{3}{*}{0.841} & \multirow{3}{*}{0.904} \\
\hline & & KPM2 & 0.863 & & & \\
\hline & & KPM3 & 0.887 & & & \\
\hline \multirow{10}{*}{4} & \multirow{10}{*}{$\begin{array}{l}\text { Komitmen } \\
\text { Merek }\end{array}$} & KMM1 & 0.675 & \multirow{10}{*}{0.617} & \multirow{10}{*}{0.930} & \multirow{10}{*}{0.941} \\
\hline & & KMM2 & 0.844 & & & \\
\hline & & KMM3 & 0.840 & & & \\
\hline & & KMM4 & 0.612 & & & \\
\hline & & KMM5 & 0.832 & & & \\
\hline & & KMM6 & 0.851 & & & \\
\hline & & KMM7 & 0.757 & & & \\
\hline & & KMM8 & 0.852 & & & \\
\hline & & KMM9 & 0.782 & & & \\
\hline & & KMM10 & 0.774 & & & \\
\hline \multirow{3}{*}{5} & \multirow{3}{*}{$\begin{array}{l}\text { Loyalitas } \\
\text { Merek }\end{array}$} & LM1 & 0.882 & \multirow{3}{*}{0.784} & \multirow{3}{*}{0.862} & \multirow{3}{*}{0.916} \\
\hline & & LM2 & 0.898 & & & \\
\hline & & LM3 & 0.876 & & & \\
\hline
\end{tabular}

Sumber: Data yang diolah SEM-PLS(2020)

Dalam uji validitas konvergen dapat digunakan untuk melihat korelasi antara nilai indikator dengan nilai konstruknya. Rule of thumb yang biasa digunakan untuk menilai validitas konvergen yaitu loading factor/outer loading yang nilainya harus berkisar antara $>0,70$ dan $>0,60$ untuk dapat diterima. Nilai indikator dalam outer loading harus lebih dari 0,7 dan nilai Average Variance Extracted (AVE) harus lebih dari 0,5 agar dapat dianggap valid. Namun, dalam penelitian tahap awal dari pengembangan, skala pengukuran outer loading 0,5-0,6 masih dapat diterima dan dianggap cukup (Ghozali \& Latan, 2015 : 74). Pada tabel 2. menunjukkan bahwa dari hasil uji reliabilitas seluruh variabel melalui uji Cronbach's Alpha dan Composite Reliability menunjukkan hasil dengan nilai diatas 0,7 maka dari itu seluruh indikator dapat dikatakan reliable.

Tabel 3. Fornel-Larcker Criterion

\begin{tabular}{|l|l|l|l|l|l|}
\hline & $\begin{array}{l}\text { Brand } \\
\text { Experience }\end{array}$ & $\begin{array}{l}\text { Kepercayaan } \\
\text { Merek }\end{array}$ & $\begin{array}{l}\text { Keterlibatan } \\
\text { Merek }\end{array}$ & $\begin{array}{l}\text { Komitmen } \\
\text { Merek }\end{array}$ & $\begin{array}{l}\text { Loyalitas } \\
\text { Merek }\end{array}$ \\
\hline Brand Experience & $\mathbf{0 , 7 6 3}$ & & & & \\
\hline Kepercayaan Merek & 0,506 & $\mathbf{0 , 8 7 1}$ & & & \\
\hline Keterlibatan Merek & 0,641 & 0,597 & $\mathbf{0 , 7 1 7}$ & & \\
\hline Komitmen Merek & 0,489 & 0,594 & 0,705 & $\mathbf{0 , 7 8 6}$ & \\
\hline Loyalitas Merek & 0,454 & 0,557 & 0,593 & 0,583 & $\mathbf{0 , 8 8 5}$ \\
\hline
\end{tabular}

Sumber: Data yang diolah (2020) 
Dalam tabel Fornell Larcker Criterion (tabel 3.) menunjukkan bahwa nilai AVE variabel korelasi Kepercayaan Merek sebesar 0,871. Nilai AVE tersebut lebih besar dibanding nilai korelasi variabel lainnya. Hal tersebut juga berlaku pada variabel lainnya dengan nilai AVE pada variabel tersebut menunjukkan angka yang lebih besar dibandingkan korelasi antar variabel. Dengan demikian maka syarat discriminant validity berdasarkan nilai AVE pada tabel Fornell Larcker Criterion telah terpenuhi dengan baik.

\section{HASIL}

Gambar 2. Path Struktural PLS Algorithm

Sumber: Hasil Olah Data SEM-PLS (2020)

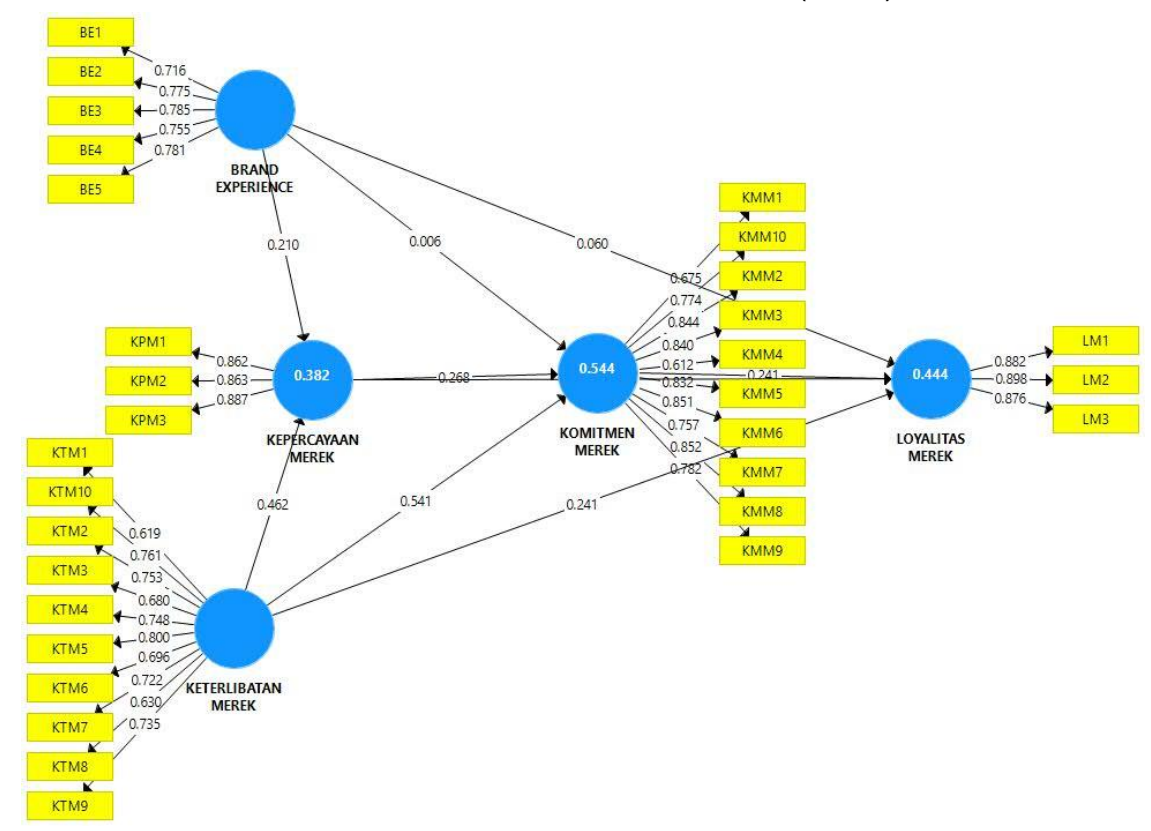

Tabel 4. Hasil $R$-Square

\begin{tabular}{|l|l|l|}
\hline & $\boldsymbol{R}$ Square & $\boldsymbol{R}$ Square Adjusted \\
\hline Kepercayaan Merek & 0,382 & 0,378 \\
\hline Komitmen Merek & 0,544 & 0,540 \\
\hline Loyalitas Merek & 0,444 & 0,437 \\
\hline
\end{tabular}

Sumber: Data yang diolah SEM-PLS (2020)

Berdasarkan tabel 4. nilai $R$-Square untuk variabel Kepercayaan Merek adalah $0,382(38,2 \%)$ sisanya sebesar $61,8 \%$ dijelaskan oleh variabel lain diluar model penelitian. Nilai $R$-Square untuk variabel Komitmen Merek adalah $0,544(54,4 \%)$ sedangkan sisanya sebesar $45,6 \%$ dijelaskan oleh variabel lain diluar model penelitian. Nilai $R$-Square untuk variabel Loyalitas Merek adalah 0,444 (44,4\%) sedangkan sisanya sebesar 55,6\% dijelaskan oleh variabel lain diluar model penelitian. Dari hasil tersebut menunjukkan nilai $R^{2}$ ketiga variabel memiliki pengaruh variabel laten eksogen terhadap variabel laten endogen yang moderate

Tabel 5. Path Coefficient

\begin{tabular}{|l|l|l|l|l|}
\hline & Beta & T Statistics & P Values & Keterangan \\
\hline BE $>$ KPM & 0.210 & $3^{* 353^{*}}$ & $\mathbf{0 . 0 0 0}^{\star}$ & Signifikan \\
\hline KTM $->$ KPM & $\mathbf{0 . 4 6 2}$ & $\mathbf{8 . 4 3 6}^{*}$ & $\mathbf{0 . 0 0 0}^{\star}$ & Signifikan \\
\hline
\end{tabular}




\begin{tabular}{|l|l|l|l|l|}
\hline KPM $->$ KMM & $\mathbf{0 . 2 6 8}$ & $\mathbf{4 . 7 1 7}^{\star}$ & $\mathbf{0 . 0 0 0}^{\star}$ & Signifikan \\
\hline KMM $->$ LM & $\mathbf{0 . 2 4 1}$ & $\mathbf{3 . 4 1 1}^{\star}$ & $\mathbf{0 . 0 0 0}^{\star}$ & Signifikan \\
\hline KPM $->$ LM & $\mathbf{0 . 2 4 0}$ & $\mathbf{3 . 7 6 6}^{\star}$ & $\mathbf{0 . 0 0 0}^{\star}$ & Signifikan \\
\hline KTM $->$ KMM & $\mathbf{0 . 5 4 1}$ & $\mathbf{9 . 7 2 1 ^ { * }}$ & $\mathbf{0 . 0 0 0}^{\star}$ & Signifikan \\
\hline KTM $->$ LM & $\mathbf{0 . 2 4 1}$ & $\mathbf{3 . 0 4 6}$ & $\mathbf{0 . 0 0 0}^{\star}$ & Signifikan \\
\hline BE $->$ KMM & 0.006 & 0.123 & 0.902 & Tidak Signifikan \\
\hline BE $->$ LM & 0.060 & 0.921 & 0.357 & Tidak Signifikan \\
\hline
\end{tabular}

$>1,96^{\star}>1,65^{\star \star}$ Significant $<0,05^{\star}<0,1^{\star *}$ Significant

Sumber: Data yang diolah SEM-PLS (2020)

Berdasarkan hasil pada tabel 5 menunjukkan bahwa Hipotesis 1, 2, 3, 4 diterima

Tabel 6. Uji Hipotesis Pengaruh Tidak Langsung

\begin{tabular}{|c|c|c|c|c|}
\hline & $\begin{array}{l}\text { Path } \\
\text { Coefficient }\end{array}$ & T Statistics & $P$ Values & Keterangan \\
\hline $\mathrm{BE}->\mathrm{KPM}->\mathrm{KMM}$ & 0.056 & 2.742 & $0.006^{*}$ & Signifikan \\
\hline KTM $->$ KPM $->$ KMM & 0.124 & 4.027 & $0.000^{*}$ & Signifikan \\
\hline $\mathrm{BE}->\mathrm{KMM}->\mathrm{LM}$ & 0.001 & 0.122 & 0.903 & $\begin{array}{l}\text { Tidak } \\
\text { Signifikan }\end{array}$ \\
\hline KTM $->$ KMM $->$ LM & 0.131 & 3.075 & $0.002^{*}$ & Signifikan \\
\hline KPM $->$ KMM $->$ LM & 0.065 & 2.842 & $0.005^{*}$ & Signifikan \\
\hline
\end{tabular}

$>1,96^{*}>1,65^{* *}$ Significant $<0,05^{*}<0,1^{* *}$ Significant

Sumber: Data yang diolah SEM-PLS (2020)

Berdasarkan hasil pada tabel 6 menunjukkan bahwa Hipotesis 5 dan 6 diterima, Hipotesis 7 ditolak, serta Hipotesis 8 dan 9 diterima

Tabel 7. Hasil Analisis Mediasi

\begin{tabular}{|c|c|c|c|c|}
\hline & Path Coefficient & T Statistics & $P$ Values & Verification \\
\hline \multicolumn{5}{|c|}{ Mediator Kepercayaan Merek } \\
\hline $\mathrm{BE}->\mathrm{KPM}$ & 0.210 & $3.353^{*}$ & $0.000^{*}$ & \multirow{3}{*}{$\begin{array}{l}\text { Memediasi Tidak } \\
\text { Langsung }\end{array}$} \\
\hline KPM ->KMM & 0.268 & $4.717^{*}$ & $0.000^{*}$ & \\
\hline $\mathrm{BE}->\mathrm{KMM}$ & 0.006 & 0.123 & 0.902 & \\
\hline KTM -> KPM & 0.462 & $8.436^{\star}$ & $0.000^{\star}$ & \multirow{3}{*}{$\begin{array}{l}\text { Mediasi } \\
\text { Komplementer }\end{array}$} \\
\hline KPM -> KMM & 0.268 & $4.717^{*}$ & $0.000^{*}$ & \\
\hline KTM -> KMM & 0.541 & $9.721^{*}$ & $0.000^{*}$ & \\
\hline \multicolumn{5}{|c|}{ Mediator Komitmen Merek } \\
\hline $\mathrm{BE}->\mathrm{KMM}$ & 0.006 & 0.123 & 0.902 & \multirow{3}{*}{$\begin{array}{l}\text { Tidak Ada Efek } \\
\text { Mediasi }\end{array}$} \\
\hline KMM -> LM & 0.241 & $3.411^{*}$ & $0.000^{*}$ & \\
\hline $\mathrm{BE}->\mathrm{LM}$ & 0.060 & 0.921 & 0.357 & \\
\hline KPM -> KMM & 0.268 & $4.717^{\star}$ & $0.000^{*}$ & \multirow{3}{*}{$\begin{array}{l}\text { Mediasi } \\
\text { Komplementer }\end{array}$} \\
\hline KMM -> LM & 0.241 & $3.411^{*}$ & $0.000^{*}$ & \\
\hline KPM -> LM & 0.240 & 3.766 & $0.000^{\star}$ & \\
\hline KTM -> KMM & 0.541 & $9.721^{*}$ & $0.000^{*}$ & \multirow{3}{*}{$\begin{array}{l}\text { Mediasi } \\
\text { Komplementer }\end{array}$} \\
\hline KMM -> LM & 0.241 & $3.411^{*}$ & $0.000^{*}$ & \\
\hline KTM -> LM & 0.241 & 3.046 & $0.000^{*}$ & \\
\hline
\end{tabular}

$>1,96^{\star}>1,65^{\star \star}$ Significant $<0,05^{\star}<0,1^{\star *}$ Significant

Data yang diolah SEM-PLS (2020)

Uji efek mediasi ditemukan hasil pada tabel 7 sebagai berikut: H5 diterima dengan Mediasi Tak Langsung; H6, H8, H9 diterima dengan Mediasi Komplementer; H7 ditolak Tidak Ada Efek Mediasi 


\section{PEMBAHASAN}

Berdasarkan hasil pengujian hipotesis pada Tabel 6 dapat terlihat bahwa Hipotesis Satu $(\mathrm{H} 1)$ diterima dikarenakan Brand Experience memiliki pengaruh langsung dan positif terhadap Kepercayaan Merek (BE->KPM). Pada penelitian sebelumnya (Khan et al., 2019) ketika pelanggan memiliki pengalaman yang menguntungkan, pelanggan merasa merek tersebut mampu memuaskan memenuhi janjinya, sehingga menghasilkan kepercayaan. Temuan dalam penelitian ini menunjukkan bahwa adanya pengaruh positif dari Brand Experience terhadap Kepercayaan Merek dapat mengindikasikan bahwa pengalaman konsumen dalam menggunakan aplikasi SOCO by Sociolla menyebabkan timbulnya kepercayaan dalam menggunakan aplikasi SOCO by Sociolla sebagai beauty e-commerce dalam berbelanja produk kecantikan. Temuan ini sejalan dengan penelitian yang dilakukan Khan et al. (2019), Huang (2017), dan Fikri et al. (2018).

Berdasarkan hasil pengujian hipotesis pada Tabel 6 dapat terlihat bahwa Hipotesis Dua $(\mathrm{H} 2)$ diterima dikarenakan Keterlibatan Merek memiliki pengaruh langsung dan positif terhadap Kepercayaan Merek (KTM->KPM). Pada penelitian sebelumnya keterlibatan merek penting dalam mengembangkan kepercayaan merek, sehingga memberikan hasil kepercayaan pada keterlibatan (Hollebeek dan Macky, 2019). Temuan dalam penelitian ini menunjukkan bahwa adanya pengaruh positif dari Keterlibatan Merek terhadap Kepercayaan Merek yang dapat mengindikasikan bahwa perilaku cognitive, affective, dan behavioral dari konsumen menyebabkan timbulnya kepercayan konsumen dalam menggunakan aplikasi SOCO by Sociolla. Temuan ini sejalan dengan penelitian yang dilakukan Khan et al. (2019) dan Fikri et al. (2018) .

Berdasarkan hasil pengujian hipotesis pada Tabel 6 dapat terlihat bahwa Hipotesis Tiga (H3) diterima dikarenakan Kepercayaan Merek memiliki pengaruh langsung dan positif terhadap Komitmen Merek (KPM->KMM) . Pada penelitian sebelumnya pelanggan yang berkomitmen cenderung menolak alternatif lain yang tersedia oleh karena itu, kepercayaan kondusif untuk pengembangan komitmen (Khan et al., 2019). Temuan dalam penelitian ini menunjukkan bahwa adanya pengaruh positif dari Kepercayaan Merek terhadap Komitmen Merek yang dapat mengindikasikan bahwa kesesuaian aplikasi SOCO by Sociolla dalam menjanjikan produk dan layanannya menyebabkan konsumen mempertahankan dan tidak menghapus aplikasi SOCO by Sociolla di smartphone mereka. Temuan ini sejalan dengan penelitian yang dilakukan Khan et al. (2019) dan Hidayanti et al. (2018)

Berdasarkan hasil pengujian hipotesis pada Tabel 6 dapat terlihat bahwa Hipotesis Empat $(\mathrm{H} 4)$ diterima dikarenakan Komitmen Merek memiliki pengaruh langsung dan positif terhadap Loyalitas Merek (KMM$>$ LM). Pada penelitian sebelumnya (Hidayanti, 2018) semakin tinggi adanya kepercayaan merek pada konsumen maka semakin tinggi juga loyalitas merek yang menghubungkan pengaruh komitmen merek pada 
loyalitas merek. Temuan dalam penelitian ini menunjukkan bahwa adanya pengaruh positif dari Temuan ini sejalan dengan penelitian yang dilakukan Khan et al. (2019), Adiba \& Syahideni (2018), Rather et al. (2018), serta Alkhawaldeh et al. (2017).

Berdasarkan hasil pengujian hipotesis pada Tabel 7 dapat terlihat bahwa Hipotesis Lima (H5) diterima dikarenakan Kepercayaan Merek memediasi secara positif pengaruh Brand Experience terhadap Komitmen Merek (BE->KPM->KMM). Temuan penelitian ini sejalan dengan temuan pada studi sebelumnya (Khan et al., 2019) yang menyatakan bahwa komitmen pelanggan bergantung pada pengalaman merek individu sebelumnya, yaitu konsumen biasanya akan berusaha untuk mengulangi pengalaman yang menyenangkan atau bermanfaat, sehingga memperkuat komitmen merek. Seperti yang dinyatakan, pengalaman yang dirasakan baik diharapkan untuk menghasilkan keinginan pelanggan untuk mengulangi pengalaman, sehingga memelihara komitmen merek mereka. Selain itu, antisipasi dari pengalaman merek secara positif menumbuhkan kepercayaan terkait merek meningkat, yang pada gilirannya akan memberikan efek peningkatan tambahan pada komitmen merek (Keiningham et al., 2017). Dalam penelitian ini konsumen telah menilai bahwa aplikasi SOCO by Sociolla menyediakan informasi yang terkini (up-to-date), tata letak fitur aplikasi yang menarik, dan hasil pencarian yang akurat maka konsumen akan bertahan pada situs beauty e-commerce aplikasi SOCO by Sociolla di masa yang akan datang dengan tetap mempertahankan aplikasi tersebut di smartphone mereka.

Berdasarkan hasil pengujian hipotesis pada Tabel 7. dapat terlihat bahwa Hipotesis Enam (H6) diterima dikarenakan Kepercayaan Merek memediasi secara positif pengaruh Keterlibatan Merek terhadap Komitmen Merek (KTM->KPM->KMM). Temuan penelitian ini sejalan dengan temuan pada studi sebelumnya (Khan et al., 2019) yang menyatakan komitmen merek sebagai konsekuensi keterlibatan di mana terdapat interaksi pelanggan dan merek yang secara kondusif membentuk keinginan konsumen di masa yang akan datang akan terus berinteraksi dengan merek tersebut. Dalam penelitian ini, konsumen telah menilai bahwa perilaku dari konsumen didukung dengan kepercayaan konsumen pada aplikasi SOCO by Sociolla yang sesuai dalam menjanjikan produk dan layanannya sehingga konsumen tidak akan menghapus aplikasi SOCO by Sociolla di saat ini dan di masa yang akan datang.

Berdasarkan hasil pengujian hipotesis pada Tabel 7. dapat terlihat bahwa Hipotesis Tujuh ( $\mathrm{H} 7)$ tidak diterima dikarenakan Komitmen Merek tidak memediasi pengaruh Brand Experience terhadap Loyalitas Merek (BE->KMM->LM). Pada penelitian sebelumnya (Khan et al., 2019) pengalaman tidak mampu menghasilkan loyalitas merek kecuali hal tersebut memunculkan respon emosional yang kuat seperti kecintaan terhadap merek. Namun hal tersebut berbanding terbalik dengan temuan yang terdapat dalam penelitian ini. Dengan konten aplikasi SOCO by Sociolla.com memberi informasi terkini, mengindikasikan bahwa informasi 
dan pengalaman tersebut tidak memberikan loyalitas kepada konsumen untuk selalu setia dan menggunakan aplikasi SOCO by Sociolla di masa yang akan datang dikarenakan konsumen lebih memilih harga produk yang lebih murah dan memberikan benefit seperti gratis biaya pengiriman dibanding dengan menggunakan aplikasi yang lebih menarik secara tampilan dan memberikan gratis biaya pengiriman dengan minimal pembelian sebesar Rp200.000 dan dengan kondisi tersebut belum tentu akan merekomendasikan beauty e-commerce Sociolla kepada orang lain. Temuan ini sejalan dengan penelitian yang dilakukan Ramaseshan (2014).

Berdasarkan hasil pengujian hipotesis pada Tabel 7. dapat terlihat bahwa Hipotesis Delapan (H8) diterima dikarenakan Komitmen Merek memediasi pengaruh Keterlibatan Merek terhadap Loyalitas Merek (KTM->KMM->LM). Pada penelitian sebelumnya ketika konsumen mengalokasikan kapasitas kognitif, mengembangkan ikatan afektif dan menginvestasikan waktu dan upaya berinteraksi dengan merek, mereka lebih cenderung mengembangkan loyalitas merek (Leckie et al., 2016). Hal tersebut membuat konsumen akan setia kepada aplikasi SOCO by Sociolla di masa yang akan datang dan akan merekomendasikan aplikasi SOCO by Sociolla kepada orang lain. Temuan ini sejalan dengan penelitian yang dilakukan Hussein (2018) dan Rather et al. (2018)

Berdasarkan hasil pengujian hipotesis pada Tabel 7. dapat terlihat bahwa Hipotesis Sembilan (H9) diterima dikarenakan Komitmen Merek memediasi pengaruh Kepercayaan Merek terhadap Loyalitas Merek (KPM->KMM->LM). Pada penelitian sebelumnya kepercayaan dapat memberikan peran penting dalam mendorong pembelian layanan online karena mengurangi risiko yang dirasakan sehingga kepercayaan merek berpengaruh secara positif terhadap loyalitas merek (Ramirez \& Merunka, 2019). Hal tersebut sejalan dengan penelitian ini, terbukti perilaku konsumen yang mempercayakan aplikasi beauty e-commerce SOCO by Sociolla dalam hal pembelian produk kecantikan yang terpikir pertama kali adalah menggunakan aplikasi beauty e-commerce SOCO by Sociolla dan konsumen merasa aplikasi beauty e-commerce SOCO by Sociolla sesuai dalam menjanjikan produk dan layanannya. Temuan ini sejalan dengan penelitian yang dilakukan Huang (2017), Adiba \& Syahideni (2018), dan Hidayanti et al. (2018)

\section{KESIMPULAN}

Brand experience yang memberikan pengalaman bagi konsumen untuk menggunakan beauty e-commerce Sociolla tidak memiliki pengaruh secara tidak langsung (tidak signifikan) terhadap Loyalitas Merek melalui komitmen merek sebagai mediasi. Hal ini dapat mengindikasikan bahwa tata letak fitur aplikasi SOCO by Sociolla.com yang menarik, aplikasi yang mudah digunakan, cepat merespon saat melakukan pencarian produk, informasi terkini (up-to-date), dan hasil pencarian yang akurat saat menelusuri aplikasi SOCO by Sociolla tidak membuat konsumen akan 
tetap setia dan menjadi pelanggan Sociolla di masa yang akan datang. Perusahaan PT Social Bella Indonesia yang menaungi beauty ecommerce Sociolla harus mempertahankan klaim terkait keaslian produk dan semua produk yang dijual sudah berizin BPOM. Suatu situs belanja online tidak cukup hanya dengan mengandalkan banyaknya kuantitas review konsumen sebelumnya, hal tersebut belum dapat membangun kepercayaan konsumen secara penuh. Situs belanja online kategori kecantikan memberikan informasi jujur tentang produk dan layanannya serta sesuai dalam menjanjikan produk dan layanannya maka konsumen akan cenderung bergantung untuk melakukan pembelian karena informasi yang ditampilkan terbaru, lengkap, relevan, dan aktual yang akan meningkatkan kepercayaan konsumen dalam melakukan pembelian berulang pada beauty e-commerce Sociolla. Penelitian selanjutnya dapat diperluas ke wilayah lain dalam melakukan pendistribusian kuisioner yang mencakup ruang lingkup lebih luas dan tersebar seperti Yogyakarta, Bandung, dan Surabaya karena semakin beragam sampel penelitian maka hasil yang diperoleh akan mampu untuk digeneralisasi untuk kondisi loyalitas merek yang lain. Penelitian selanjutnya diharapkan untuk dapat menguji juga variabel e-WOM dikarenakan variabel tersebut dalam penelitian lain juga dapat memengaruhi loyalitas merek bagi konsumen yang melakukan pembelian secara online.

\section{DAFTAR PUSTAKA}

Adiba, F., dan Syahideni, M. Y. (2018). The Influence of Brand Trust and Brand Commitment to Brand Loyalty at Consumer Society of AQUA Products in Dadaprejo - Junrejo - Batu City - Indonesia. European Journal of Business and Management, 10(11): 185-194.

Alkhawaldeh, A. M., Al-Salaymeh, M., Alshare, F., dan Eneizan, B. M. (2017). The Effect of Brand Awareness on Brand Loyalty: Mediating Role of Brand Commitment. European Journal of Business and Management, 9(36): 38-47.

Andriani, D. (11 Oktober 2019). Penjualan Produk Kecantikan Melalui Online Terus Melesat. URL https://ekonomi.bisnis.com/read/20191011/12/1158058/penjualanproduk-kecantikan-melalui-online-terus-melesat:

Bilgihan, A., Kandampully, J., dan Zhang, T. C. (2016). Towards a Unified Customer Experience in Online Shopping Environments. International Journal of Quality and Service Sciences, 8(1):102-119.

CNNIndonesia. (6 Februari 2020). Tren dan Peluang Industri E-Commerce di Indonesia $2020 . \quad$ URL https://www.cnnindonesia.com/teknologi/20200205204206-206472064/tren-dan-peluang-industri-e-commerce-di-indonesia-2020:

Fikri, I., Yasri, Y., dan Abror, A. (2018). The Impact of Brand Experience and Brand Trust on Brand Engagement: The Mediating Effect of Brand Satisfaction. Advances in Economics, Business and Management Research, 57: 153-161. 
Frimpong, K. O., Donkor, G., dan Frimpong, N. O. (2019). The Impact of Celebrity Endorsement on Consumer Purchase Intention: An Emerging Market Perspective. Journal of Marketing Theory and Practice, 27(1): 103-121.

Ghozali, I., dan Latan, H. (2015). Partial Least Squares, Konsep, Teknik dan Aplikasi Menggunakan Program SmartPLS 3.0 untuk Penelitian Empiris. Semarang: Badan Penerbit UNDIP.

Hidayanti, I., Nuryakin, dan Farida, N. (2018). A Study on Brand Commitment and Brand Trust towards Brand Loyalty of Branded Laptop in Indonesia. Journal of Business and Retail Management Research, 12(3): 270-278.

Hollebeek, L., dan Macky, K. (2019). Digital Content Marketing's Role in Fostering Consumer Engagement, Trust, and Value: Framework, Fundamental Propositions, and Implications. Journal of Interactive Marketing, 45: 27-41.

Huang, C. C. (2017). The Impacts of Brand Experiences on Brand Loyalty: Mediators of Brand Love and Trust. Management Decision , 55(5): 915-934.

Hussein, A. S. (2018). Revisiting the Importance of Casual Dining Experience Quality: an Empirical Study. International Journal of Quality and Service Sciences, 10(3): 233-252.

Keiningham, T., Ball, dan Dzenkovska, J.(2017). The Interplay of Customer Experience and Commitment. Journal of Services Marketing, 31(2): 148-160.

Khan, I., Hollebeek, L. D., Islam, M. F., dan Rahman, Z. (2019). Brand Engagement and Experience in Online Services. Journal of Services Marketing, 163-175.

Leckie, C., M., N., L., J. (2016). Antecedents of Consumer Brand Engagement and Brand Loyalty. Journal of Marketing Management, 32(5): 558-578.

Ramaseshan, B. (2014). Connecting the Dots between Brand Experience and Brand Loyalty: The Mediating Role of Brand Personality and Brand Relationships. Journal of Brand Management, 21(7/8): 664683.

Ramirez, R. H., dan Merunka, D. (2019). Brand Experience Effects on Brand Attachment: The Role of Brand Trust, Age, and Income. European Business Review, 31(5): 610-645.

Rather, R. A., Tehseen, S., dan Parrey, S. H. (2018). Promoting Customer Brand Engagement and Brand Loyalty through Customer Brand Identification and Value Congruity. Spanish Journal of Marketing ESIC, 22(3): 321-339.

Yusra, Y. (13 Oktober 2015). Memperkenalkan fitur baru "Pick Your Free Sample" untuk seluruh pelanggan. URL https://dailysocial.id/post/sociolla-online-shopping-platform 